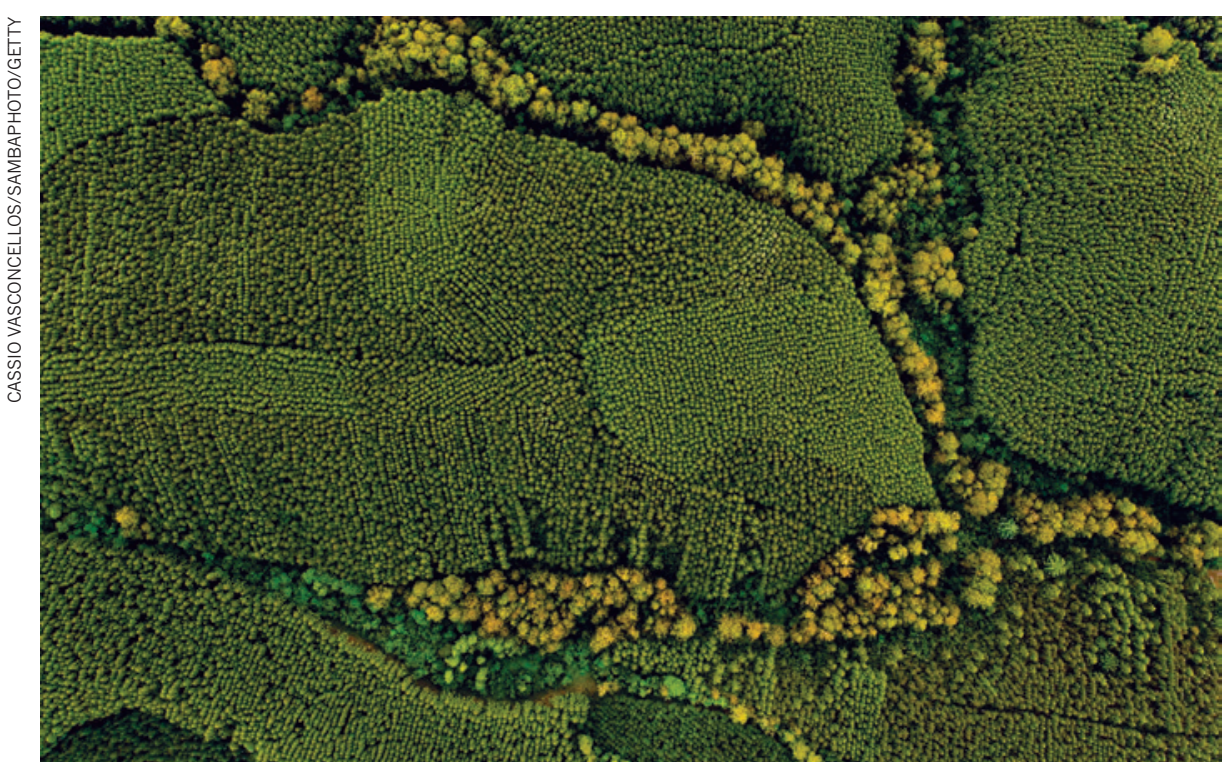

Eucalyptus plantations near São Paulo in Brazil.

BIOTECHNOLOGY

\title{
Brazil considers transgenic trees
}

\section{Genetically modified eucalyptus could be a global test case.}

\section{BY HEIDI LEDFORD}

$\mathrm{V}$ iewed from above, Brazil's orderly eucalyptus plantations offer a stark contrast to the hurly-burly of surrounding native forests. The trees, lined up like regiments of soldiers on 3.5 million hectares around the country, have been bred over decades to grow quickly.

On 4 September, a public hearing will consider bringing an even more vigorous recruit into the ranks: genetically engineered eucalyptus that produces around $20 \%$ more wood than conventional trees and is ready for harvest in five and a half years instead of seven. Brazilian regulators are evaluating the trees for commercial release; a decision could come as early as the end of this year.

Researchers, businesses and activists are watching closely. Eucalyptus (Eucalyptus spp.) - native to Australia - is grown on about 20 million hectares throughout the tropics and subtropics, and approval of the genetically engineered trees in Brazil could encourage their adoption elsewhere. "It would have ripple effects worldwide," says Zander Myburg, who studies the genetics of forest trees at the University of Pretoria in South Africa. "Everybody will pay attention."

So far, no genetically modified tree from a major commercial species has been deployed on a large scale. The ubiquity of eucalyptus makes Brazil's decision on the modified trees a special concern to environmental activists who oppose the use of genetically modified crops.

"They have become the target of very intensive and emotionally charged debate particularly among the NGOs and nature constituencies," says Walter Kollert, a forestry officer with the Food and Agriculture Organization of the United Nations in Rome.

A consortium of activists opposed to the plan intends to present a letter at the 4 September meeting, urging Brazil's National Technical Biosafety Commission to reject the trees. In all, 259 organizations - 106 of them from Latin America - have signed the letter, which expresses concern that the trees pose risks to the environment and will encourage the expansion of plantations.

The trees were developed by FuturaGene, a biotechnology firm in Rehovot, Israel, that was spun out of the Hebrew University in Jerusalem in 1993. The company found that certain proteins accelerate plant growth by facilitating cell-wall expansion. FuturaGene inserted into eucalyptus a gene that encodes one such protein from thale cress (Arabidopsis thaliana), a common laboratory plant. In 2010, the firm was bought by Suzano Pulp and Paper of São Paulo, Brazil, one of the world's largest producers of eucalyptus pulp.
FuturaGene's chief executive Stanley Hirsch is quick to point out the environmental benefits of his company's creation. The tree's speedy growth boosts absorption of carbon dioxide from the air by about $12 \%$, he says, aiding in the fight to reduce greenhouse-gas emissions. The genetically modified trees may also require less land to produce the same amount of wood, reducing the conversion of natural forest into plantations.

Hirsch says that the company has tried to avoid public-relations mistakes made by agricultural biotechnology companies in the past: rather than shun activists, he has invited them to tour the company's field-trial sites. "Some of them were so surprised," he says. "They said, 'Wow, these look just like normal trees."

Hirsch's pitch has not convinced everyone. Anne Petermann, executive director of the nonprofit organization Global Justice Ecology Project in Buffalo, New York, says that FuturaGene is trying to stave off opposition by 'greenwashing' its product. Faster-growing trees require more water and extract more nutrients from the soil, she adds, and they will only add to the economic incentive to seed more plantations.

Genetically engineered trees do pose some biosafety issues that do not apply to agricultural crops such as maize (corn) or soya, notes forest geneticist Steven Strauss of Oregon State University in Corvallis. They remain in the environment for years, increasing their potential impact on the plants, animals and soil around them. And trees tend to disperse pollen further than crops nearer the ground do, raising concerns about gene flow to native relatives. But eucalyptus has no native relatives in Brazil and is not particularly invasive in most areas of the country, says Strauss.

FuturaGene says that it identified no major environmental problems in eight years of field trials that collected data on everything from gene flow to leaf-litter decomposition to the composition of honey made by bees that visit the trees. Myburg, who does not work with FuturaGene but is familiar with the company's safety data, says that he found the firm's studies to be well designed and thorough.

While FuturaGene tests the waters in Brazil, a US company awaits a regulatory decision regarding its genetically engineered, freezetolerant eucalyptus. In 2008, ArborGen of Ridgeville, South Carolina, petitioned the US Department of Agriculture to allow commercialization of the trees in the southeastern United States. Delays of this length are not uncommon in the US regulatory system, says ArborGen's director of regulatory affairs Leslie Pearson.

For now, just the prospect that the trees might be approved has been enough to rally activists. "The fact that there are now two commercial applications has the movement against genetically modified trees mobilizing quickly in many regions," says Petermann. "We know we're going to be seeing a lot more coming out from this industry." - 